\title{
Migration of coccinellids to alfalfa fields with varying adjacent vegetation in Central Chile
}

\author{
Audrey A. Grez ${ }^{1}$, Constanza Torres ${ }^{1}$, Tania Zaviezo², Blas Lavandero³, and \\ Marcelo Ramírez ${ }^{1}$ \\ ${ }^{1}$ Facultad de Ciencias Veterinarias y Pecuarias, Universidad de Chile, Casilla 2, Correo 15, La Granja, Santiago, Chile. \\ ${ }^{2}$ Facultad de Agronomía e Ingeniería Forestal, Pontificia Universidad Católica de Chile, Casilla 306-22, \\ Santiago, Chile. \\ ${ }^{3}$ Instituto de Biología Vegetal y Biotecnología, Universidad de Talca, 2 Norte 685, Talca, Chile.
}

\begin{abstract}
A. A. Grez, C. Torres, T. Zaviezo, B. Lavandero, and M. Ramírez. Migration of coccinellids to alfalfa fields with varying adjacent vegetation in Central Chile. 2010. Cien. Inv. Agr. 37(2): 111-121. Permanent and permeable edges, where natural enemies can feed, overwinter or easily cross over, should enhance the early arrival of these predators to crops. We evaluated the abundance and species richness of coccinellids migrating to alfalfa fields adjacent to Eucalyptus, a mix of false acacia, blackberries and poplar (F-B-P), vineyards, corn and annual vegetables. From September 2007 to May 2008, we captured coccinellids in three sticky traps $\left(2.64 \mathrm{~m}^{2}\right)$ placed at the borders between alfalfa fields and adjacent vegetation. We also estimated the abundance of aphid populations in the alfalfa fields, by counting the number of individuals per alfalfa stem in spring, summer and autumn. We collected 90,396 coccinellids from 14 species. Neither total abundance nor species richness of coccinellids was significantly affected by adjacent vegetation, but Adalia deficiens, Psyllobora picta and Cycloneda sanguinea were more abundant in alfalfa adjacent to Eucalyptus and F-B-P, meanwhile Olla v-nigrum next to annual crops and Hyperaspis sphaeridioides next to vineyards. Edge height and orientation explained $94 \%$ of the variance in species abundance. Particularly, P. picta and $O$. v-nigrum were positively and negatively influenced by border height, respectively. Hyperaspis sphaeridioides was negatively affected by northern exposure and none of the species was affected by edge permeability. Aphids were less abundant in alfalfa fields adjacent to F-B-P, especially in spring. These results show that most species of coccinellids were not affected by the composition of crop edges, although tall permanent edges may enhance the arrival of particular coccinellid species to alfalfa fields.
\end{abstract}

Key words: agroecosystems, conservation biological control, edge effects, ladybeetles, migration, natural enemies.

\section{Introduction}

There is an increasing awareness that in agricultural landscapes non-farmed areas surrounding crops are an essential part of crop habitats (Hol-

Received August 11, 2009. Accepted November 25, 2009. Corresponding author: agrez@uchile.cl land et al., 2005; Blackshaw and Vernon, 2006). They are composed by different types of habitat such as forests, hedgerows, field margins, fallows and meadows, which are temporally more stable and heterogeneous environments than annual, arable crops (Tscharntke et al., 2007). Additionally, they provide several important resources for natural enemies of pests, like alternative prey, refuge from disturbance and overwin- 
tering sites (Sutherland et al., 2001). These characteristics can enhance the survival, fecundity, longevity, and dispersal behaviour of natural enemies, increasing their rapid colonization of adjacent crops and the effective control of pest populations (Duelli and Obrist, 2003). The loss of these habitats would also reduce the number of species that could recolonize crops (Concepción et al., 2008). Therefore, field edges may contribute to conservation biological control and must be considered in the management of agricultural landscapes (Landis et al., 2000; Benton et al., 2003; Holland et al., 2004; Pollard and Holland, 2006; Griffiths et al., 2008; Gardiner et al., 2009; Holland et al., 2009). Although these habitat structures have generally been lost in modern intensive agricultural landscapes (Lindborg et al., 2008), some neighboring crops can act also as a source of natural enemies (Grez and Prado, 2000), depending on their composition, structure and permanence, in diverse agricultural landscapes with a mixture of annual and perennial crops.

Alfalfa crops (Medicago sativa Linnaeus) allow the development of a variety of insect pests, including many species of aphids (Apablaza and Stevenson, 1995; Blackman and Eastop, 2000). Coccinellids are among the most efficient and abundant biological control agents of aphids, playing an important role in keeping aphid densities low (Obrycki and Kring, 1998; Dixon, 2000). In central Chile, several native and exotic species of coccinellids are commonly found in alfalfa crops (Zaviezo et al., 2004; 2006; Grez et al., 2008). However, although alfalfa fields last for about five years, during each growing season they experience up to seven or eight cuts starting in October, which may increase the risk of coccinellid mortality. Thus, understanding which type of crop edge functions as a permanent source of these natural enemies and enhances coccinellid migration to alfalfa fields may be important in the design of agricultural landscapes, keeping aphid populations low.

The aim of this study was to evaluate the abundance and species richness of coccinellids migrating to alfalfa crops adjacent to different types of edges. We also aimed to estimate aphid populations in the alfalfa fields. We expect that permanent and diverse edges will enhance the arrival of these enemies to alfalfa fields, rendering lower aphid populations compared to adjacent annual crops.

\section{Materials and methods}

The study was carried out in Pirque ( $33^{\circ} 38^{\prime} \mathrm{S}$; $\left.70^{\circ} 33^{\prime} \mathrm{W}\right), 16 \mathrm{~km}$ south of Santiago, Chile, in a mosaic landscape composed of a variety of crops, including vineyards, grains, horticultural crops and alfalfa fields, separated from each other by various field boundary structures (Figure 1a).

We selected ten alfalfa fields between 5 and 20 ha, at least 2 years-old, with edges varying in height, composition and permanence (Table 1), grouped in five different boundary types:

a) Tall, monospecific and permanent edges, composed by Eucalyptus globulus Labill. (Figure $1 b)$.

b) Tall, diverse and permanent edges, composed by a mix of false acacia (Robinia pseudoacacia L.), blackberries (Rubus ulmifolius Schott) and poplar (Populus spp.) (F-B-P) (Figure 1c).

c) Medium height, monospecific and permanent edges, composed by vineyards (Vitis spp.) (Figure 1d).

d) Medium height, monospecific and nonpermanent edges, composed by corn (Zea mays L.) (Figure 1e).

e) Short, monospecific and non-permanent edges, composed by annual vegetables: potatoes (Solanum tuberosum L.) and pumpkins (Cucurbita maxima Dutch) (Figure 1f).

Each type of edge was replicated twice with the exception of corn in March when one field was plowed. We considered an edge as permanent if during the whole study period its presence remained invariable. The non-permanent edges (annual crops) were composed by bare ground both at the beginning (spring: September to October) and at the end of the study (autumn: end of March to May). Alfalfa fields were georeferenced (Figure 1a) with a GPS (Garmin eTrex Vista Cx). Edge permeability was estimated taking into account the relative compact- 

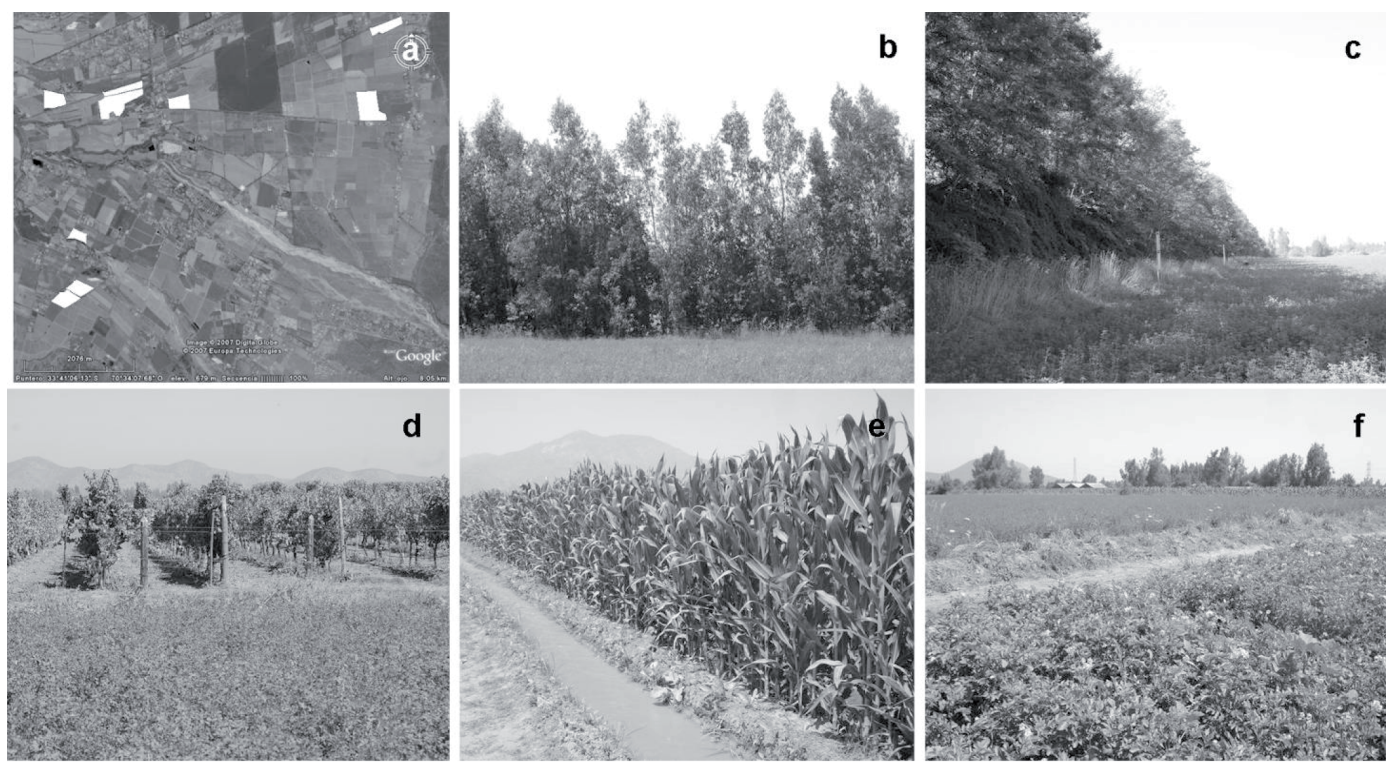

Figure 1. Location of the studied alfalfa crops (a) and edge vegetation: Eucalyptus (b), mix of false acacia, blackberries and poplar (F-B-P) (c), vineyards (d), corn (e) and annual vegetables (f). Image of the landscape was taken from Google Earth 2007.

ness of the foliage, with annual vegetables being the most permeable and F-B-P less permeable to coccinellid dispersal (Table 1).

\section{Insect sampling}

From the $12^{\text {th }}$ of September 2007 (early spring in the southern hemisphere) to the $26^{\text {th }}$ of May 2008 (autumn), three double-sided sticky traps (Duelli et al., 1990), separated by $30 \mathrm{~m}$, were simultaneously placed at the boundary $(0 \mathrm{~m})$ of each alfalfa field, at least $20 \mathrm{~m}$ from each corner. The sticky traps consisted of two wooden squares $\left(0.66 \mathrm{~m}^{2}\right.$ each $)$ mounted at 1 to $3 \mathrm{~m}$ height on wooden poles. Each side of the traps was covered with a yellow plastic film, smeared with water-resistant insect glue (Point Sticky Glue ${ }^{\circledR}$ ), which was replaced every 15 days (ten times in total). The four plastic films of each trap (capture surface per trap: $2.64 \mathrm{~m}^{2}$ ) were brought to the laboratory where all coccinellids were counted and identified to the species level, based on a reference collection and on González (2006).

Aphid populations in alfalfa fields were estimated in three occasions throughout the season: in spring (September-October), summer (December-January) and autumn (April-May). In each alfalfa field, aphids were sampled at 42 points in a grid of seven transects and six sampling points in each, within $100 \mathrm{~m}$ from the edge. We assumed that in this area aphid abundance would be affected more by the type of edge that we were sampling than further into the interior area of the crop. Samples were taken when alfalfa cover was $100 \%$ and at least $40 \mathrm{~cm}$ high, by removing the apical $20 \mathrm{~cm}$ of three stems in each sampling point. Aphids were counted in the laboratory, and identified at species level (Artigas, 1994).

\section{Data analyses}

To avoid pseudoreplication (Hurlbert, 1984), we averaged the number of individuals or species captured in the three sticky traps for coccinellids and 42 sampling points for aphids of each alfalfa field. With that information, we performed the statistical analyses. Data were $\log (\mathrm{x}+1)$ transformed and analyzed by repeated measures analyses of variance (rmANOVA) for the effect of the type of edge on the total abundance, species richness and the abundance of the most abundant 
Table 1. Characteristics of the studied alfalfa fields and type of edge vegetation.

\begin{tabular}{|c|c|c|c|c|c|}
\hline Alfalfa field code & Edge composition & $\begin{array}{l}\text { Edge height } \\
(\mathrm{m})\end{array}$ & Edge permanence & $\begin{array}{c}\text { Edge permeability } \\
(\%)\end{array}$ & $\begin{array}{c}\text { Edge orientation } \\
\text { (degrees**) }\end{array}$ \\
\hline Field E1 & Eucalyptus & $15-20$ & Permanent & 0.4 & 160 \\
\hline Field E2 & Eucalyptus & $15-20$ & Permanent & 0.1 & 210 \\
\hline Field F-B-P 1 & $\begin{array}{l}\text { False acacia- } \\
\text { Blackberry-poplar }\end{array}$ & $10-15$ & Permanent & 0 & 350 \\
\hline Field F-B-P 2 & $\begin{array}{l}\text { False acacia- } \\
\text { Blackberry-poplar }\end{array}$ & $10-15$ & Permanent & 0 & 340 \\
\hline Field V1 & Vineyard & 2 & Permanent & 0.5 & 260 \\
\hline Field V2 & Vineyard & 2 & Permanent & 0.5 & 130 \\
\hline Field $\mathrm{C} 1 *$ & Corn & 2 & Non-permanent & 0.3 & 270 \\
\hline Field C2* & Corn & 2 & Non-permanent & 0.3 & 60 \\
\hline Field AV1* & Vegetables: Potatoes & $<0.5$ & Non-permanent & 0.9 & 110 \\
\hline Field AV2* & $\begin{array}{l}\text { Vegetables: } \\
\text { Pumpkins }\end{array}$ & $<0.5$ & Non-permanent & 0.9 & 90 \\
\hline
\end{tabular}

*In spring and autumn these fields were surrounded by bare ground.

** $360^{\circ}$ corresponds to North.

species of coccinellids and aphids, with time as the repeated measure. The low abundances of $C$. eryngii, S. bicolor and S. loewii precluded any statistical analyses at the species level. ANOVA assumptions were tested with the Shapiro Wilk test for normality, and Cochran, Hartley and Bartlett test for homocedasticity (Sokal and Rohlf, 1995). For multiple comparisons we used Tukey's test. All these analyses were performed in Statistica 7.0 (Statsoft Inc., 2001).

Additionally, as a data exploratory technique, we performed canonical correspondence analyses (CCA) to examine the relationship between coccinellid assemblages in alfalfa plots and environmental variables describing different types of adjacent vegetation. CCA is a constrained ordination technique whose first axis is a linear combination of environmental variables that best explains variation in a matrix of species abundances (ter Braak and Smilauer, 1998; Leps and Smilauer, 2003). Additionally, orthogonal axes explain the remaining variance in the community data. Analyses were performed using CANOCO v4.5 for windows (ter Braak and Smilauer, 2002). The environmental variables used to describe the different field edges were height $(\mathrm{m})$, permeability (proportion) and edge orientation (degrees) (Table
1). Environmental variables were transformed as necessary to achieve normality mainly to reduce skewness in order to improve performance (Legendre and Legendre, 1998), using arcsin for proportion data (permeability), cosine of radian for orientation and $\ln (\mathrm{x})$ for border height. Species data corresponded to the mean coccinellid abundance of the 13 most common species per alfalfa field, throughout the season.

\section{Results}

We collected 90,396 coccinellids from 14 species: Scymninae Hyperaspis sphaeridioides (Mulsant), Scymnus bicolor (Germain), Scymnus loewii Mulsant, Coccinellinae Adalia bipunctata (Linnaeus), Adalia deficiens Mulsant, Adalia angulifera Mulsant, Cycloneda eryngii (Mulsant), Cycloneda sanguinea (Linnaeus), Eriopis connexa (Germar), Hippodamia convergens Guerin, Hippodamia variegata (Goeze), Olla v- nigrum (Mulsant), Psyllobora picta (Germain), and Harmonia axyridis (Pallas). Six of these species are exotics: A. bipunctata, $H$. convergens, $H$. variegata and $H$. axyridis, deliberately introduced to the country as biocontrol agents and $S$. loewii and $O$. 

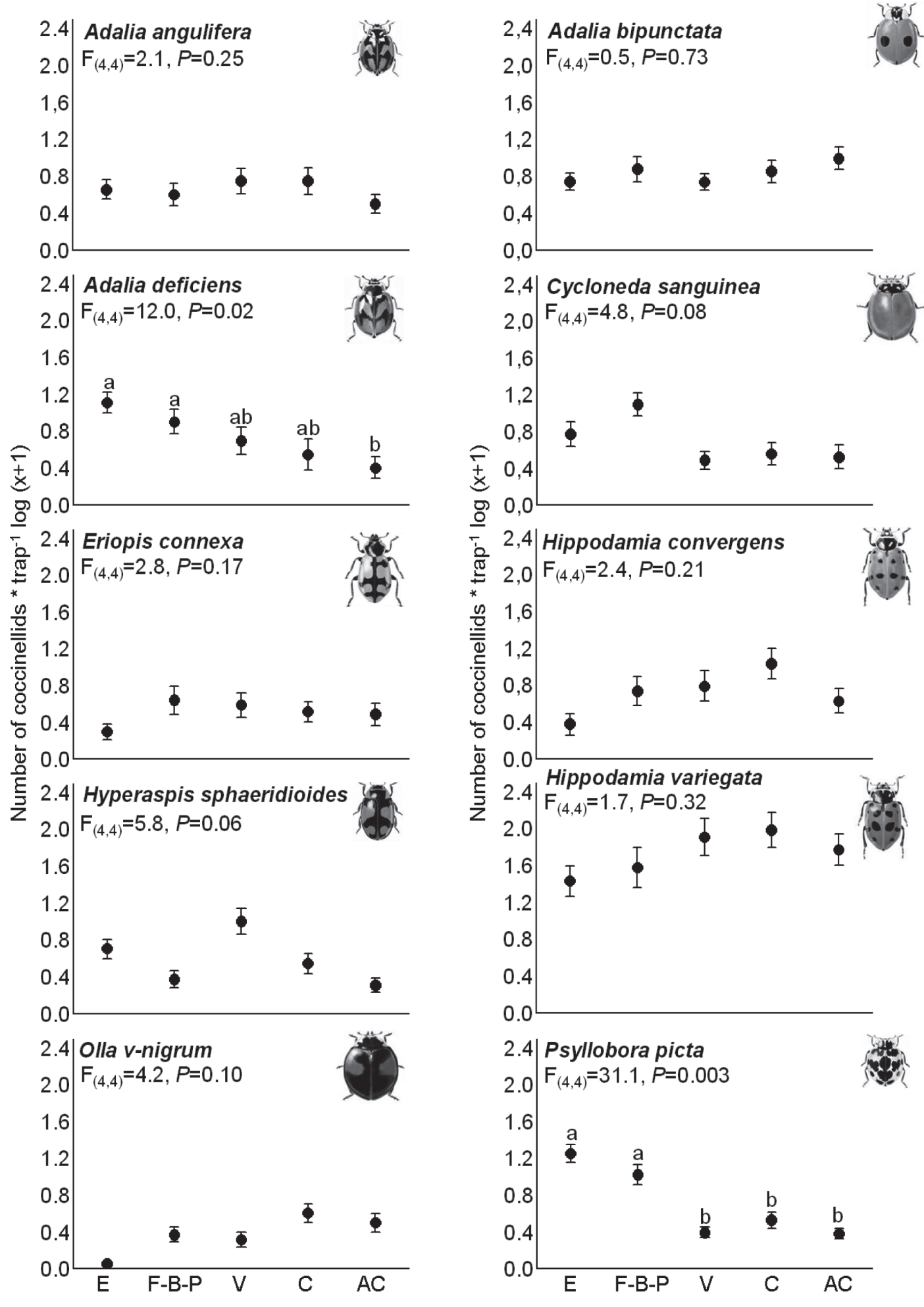

Figure 2. Effect of edge type on the abundance of coccinellid species (mean per trap $\pm 1 \mathrm{SE}$ ) migrating to alfalfa fields. Different letters mean statistically significant differences (Tukey Test, $\mathrm{P}<0.05$ ). E: Eucalyptus, F-B-P: mix of false acacia, blackberries and poplar, V: vineyards, C: corn AV: annual vegetables. 


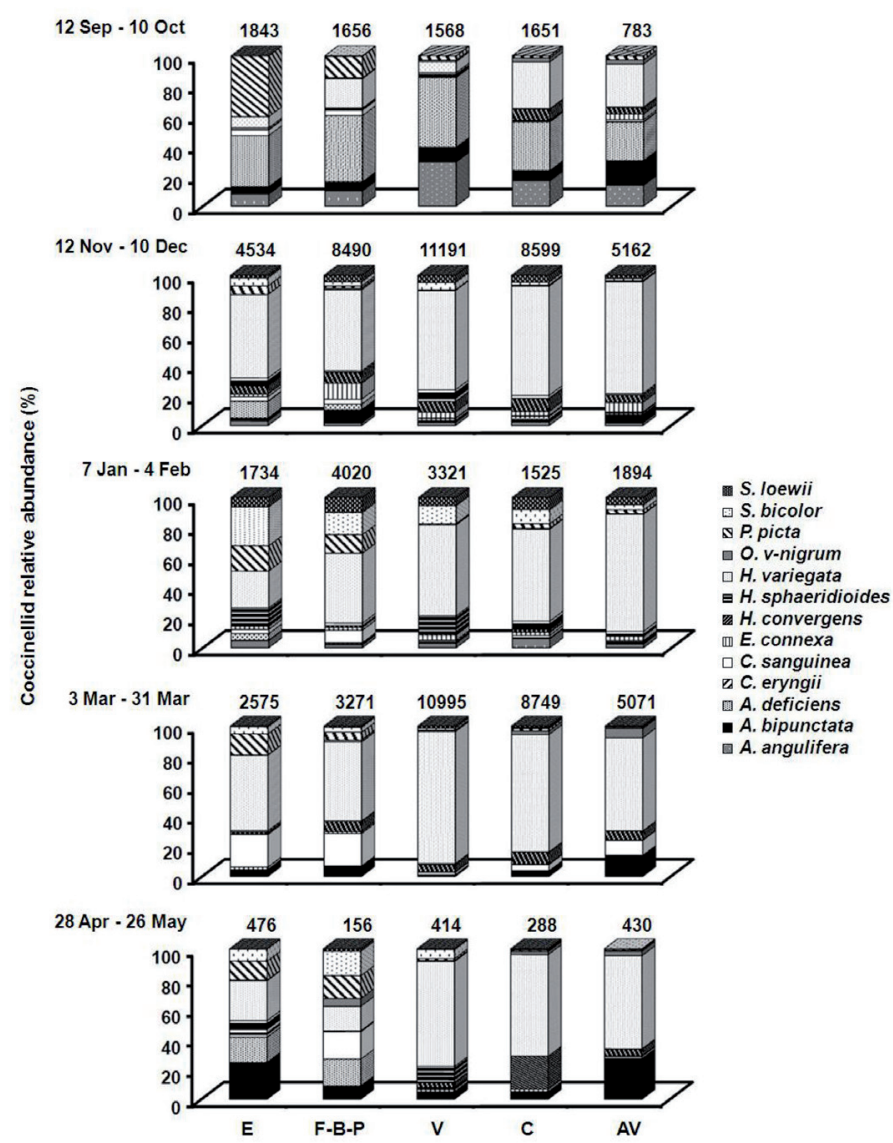

Figure 3 Relative abundance of coccinellid species migrating to alfalfa fields from $12^{\text {th }}$ of September, 2007 to $26^{\text {th }}$ of May, 2008. Samples were pooled by month. Total number of individuals collected is also indicated for each type of edge vegetation. In the last sampling month, one of the alfalfa fields next to corn was sown. E: Eucalyptus, F-B-P: mix of false acacia, blackberries and poplar, V: vineyards, C: corn, AV: annual vegetables.

v-nigrum, accidentally introduced. Among the native species $H$. sphaeridioides is endemic (Rojas, 2005; González, 2008). The most abundant species was by far $H$. variegata, with $62 \%$ of all collected individuals, followed by H. convergens $(5.4 \%)$, A. deficiens $(4.9 \%)$, and A. bipunctata (4.2\%), whereas the rarest species were $C$. eryngii $(0.03 \%)$ and $O$. v-nigrum $(1.1 \%)$. The five exotic species accounted for $75.7 \%$ of the total collected individuals. Only once $H$. axyridis was collected throughout the study period.

The different species varied their abundance through time (rmANOVA, $\mathrm{F}_{(9,36)}>9.02, P<0.001$ for all). Some of them had one peak of abundance in spring (A. deficiens and E. connexa), others peaked in summer (H. sphaeridioides) or autumn (C. sanguinea and $O$. v-nigrum), while A. bipunctata, $H$. convergens, and $H$. variegata showed two peaks, one in spring and one in autumn.

Neither the total abundance nor the species richness of coccinellids migrating to alfalfa fields were significantly affected by the type of edge vegetation (Total abundance: $\mathrm{F}_{(4,4)}=0.78, P=$ 0.59; Species richness: $\left.\mathrm{F}_{(4,4)}=0.85, P=0.56\right)$, but at the species level $P$. picta and $A$. deficiens were significantly more abundant in alfalfa borders adjacent to Eucalyptus and F-B-P (Figure 2). In the case of $P$. picta, populations next to vineyards and corn were also low. Cycloneda sanguinea tended to be more abundant next to tall permanent edges, although not statistically significant. Hyperaspis sphaeridioides was not significantly affected by the type of edge vegetation, but it was more abundantly captured in alfalfa borders next to vineyards (Figure 2). None of the species showed a significant Edge * Date interaction $(P>0.05)$. 
The composition and relative abundance of coccinellid assemblages varied in the alfalfa fields next to different types of edge vegetation and through time (Figure 3). At the beginning of the study, the dominant species generally was $A$. deficiens (over $25 \%$ in all fields), although P. picta was relatively more abundant next to Eucalyptus edges (40\%) and $H$. variegata next to both annual crops ( $31 \%$ and $28 \%$ in corn and annual vegetables, respectively). In November, when coccinellid numbers increased, $H$. variegata became the dominant species in all fields (over 53\%), and this was maintained until the end of March, with the exception of fields next to Eucalyptus in January where other species like P. picta (16\%) and S. bicolor (26\%) were also abundant. The abundance of $C$. sanguinea increased in the tall permanent edges in March (over $21 \%$ ). By the end of autumn, coccinellids became less abundant, being only $2 \%$ of the total coccinellids captured during the whole study. At this time, $H$. variegata dominated only in fields next to vineyards and annual crops, representing more than $62 \%$ of the total coccinellids captured (Figure 3).

Aphid populations in spring were 3 and 2.5 times more abundant than in summer and autumn, respectively $\left(\mathrm{F}_{(2,10)}=6.86, P=0.013\right)$. Three species dominated: Aphis craccivora Koch, Acyrthosiphum pisum (Harris) and Therioaphis trifolii (Monell), all of them reported as common species attacking this crop in Central Chile (Apablaza and Stevenson, 1995). The total abundance of aphids in alfalfa fields was not affected by the type of edge $\left(\mathrm{F}_{(4,5)}=0.51, P=0.73\right)$, but in spring, they tended to be less abundant in the alfalfa fields adjacent to F-B-P $\left(\mathrm{F}_{(8,10)}=2.90, P=0.059\right.$; Figure 4).

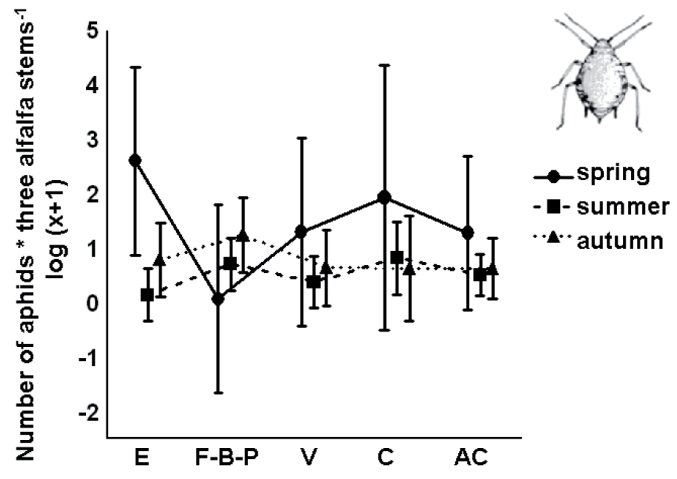

Figure 4. Effect of edge type on the abundance of aphids in alfalfa fields (mean per three alfalfa stems $\pm 1 \mathrm{SE}$ ). E: Eucalyptus, F-B-P: mix of false acacia, blackberries and poplar, V: vineyards, C: corn, AV: annual vegetables.
The CCA indicates that $94 \%$ of the variance is explained by edge height combined with orientation. Species abundance was strongly associated with the environmental variables $(\mathrm{F}=5.77, P=0.002$; Monte Carlo Test). Psyllobora picta was strongly influenced by height, while $S$. bicolor, A. deficiens and $C$. sanguinea were moderately influenced by height, and $O$. v-nigrum was negatively affected by it (Figure 5). Hyperaspis sphaeridioides was negatively affected by borders with a northern exposure, compared to the orientation of the other borders. Hippodamia variegata and $H$. convergens responded in a similar way to both orientation and border height (Figure 5). Permeability explained some of the variability in CCA1 that is not explained by height (Figure 5).

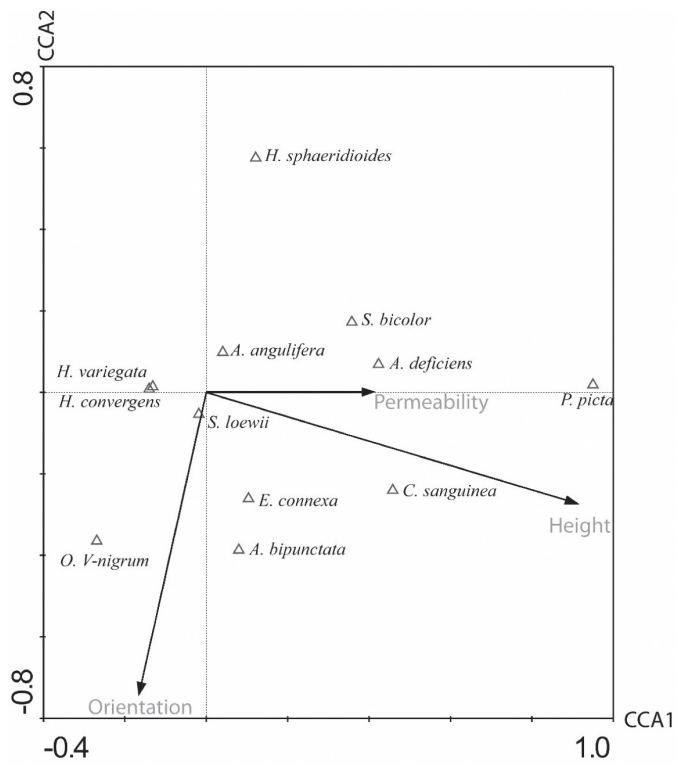

Figure 5. Bi-plot of canonical correspondence analysis The first two canonical axes explain $94 \%$ of the total variance. Axis one (CCA1) and two (CCA2) discriminated differences in field borders in height and orientation respectively. Bi-plot shows the border height vector $(r=$ 0.90 with CCA1); border orientation vector $(r=-0.63$ with CCA2); and border permeability vector $(r=0.58$ with CCA1). The relative positions of the different coccinellid species are shown.

\section{Discussion}

Although crop edges did not affect the total abundance or species richness of coccinellids migrating to alfalfa fields, our results showed that they differentially influenced coccinellid species. Both, rmANOVA and CCA showed that some of the coccinellids were 
favoured by tall edges. For instance, $P$. picta, $A$. deficiens and $C$. sanguinea, were more abundant in alfalfa adjacent to Eucalyptus and F-B-P vegetation types. Contrary, O. v-nigrum was negatively affected by edge height, with lower abundances in the borders of alfalfa fields next to Eucalyptus. Furthermore, permeability was not an important environmental variable explaining the relative abundance of coccinellids migrating to alfalfa fields.

Several studies have demonstrated the importance of woody vegetation for coccinellids as hibernation sites or alternative food sources (Honek and Hodek, 1996; Dixon, 2000; Honek et al., 2007; Gardiner et al., 2009). For example, coccinellids in soybean fields in USA were positively related to agricultural landscapes characterized by the presence of forested areas as compared with landscapes dominated by agricultural crops, and this resulted in more efficient control of aphid populations (Gardiner et al., 2009). In our study sites, it was frequent to see several aphidophagous coccinellid species aggregated on the bark of trees in winter, like C. sanguinea in False acacia and A. bipunctata in Eucalyptus. Additionally, during the growing season we commonly observed abundant populations of A. craccivora in False acacia, demonstrating the presence of alternative prey in these edges. In the case of $P$. picta, that feeds on powdery mildew (CSIRO, 1996), edges with trees provide more suitable conditions for the development of these fungi, and this may be the reason why the species was associated with this type of edge and was not found within the alfalfa fields.

Theoretically, higher abundances of some coccinellids migrating to alfalfa fields from tall boundaries should be accompanied by lower abundance of aphids in those fields. Our results partially supported this statement since aphids tended to be less abundant in alfalfa fields adjacent to F-B-P, particularly in spring, and being more numerous in the other alfalfa fields. Thus, the early arrival of natural enemies to alfalfa fields with F-B-P boundaries may have suppressed the establishment of aphid populations there, as it has been recorded to occur with spiders in agricultural landscapes in Germany (Öberg et al., 2008). Nevertheless, the opposite occurred in alfalfa fields adjacent to Eucalyptus where aphids were also very abundant. This may be explained by the species composition of the migrating coccinellids, dominated by fungivorous $P$. picta in Eucalyptus, and by aphidophagous $A$. deficiens and $H$. variegata in F-BP. Therefore, it seems that not only edge height but also the plant composition may affect coccinellid migration and, therefore, aphid control.

On the other hand, coccinellids were captured throughout the season, with the lowest abundance and species richness in early spring and late fall, during the time when they are more active in the agricultural landscapes. The seasonal distribution and abundance of the thirteen species varied, with some of them having two peaks in spring and autumn, while others only one peak of abundance in spring or fall, but most of them coexisting throughout the season. The number of peaks probably indicates the number of generations of each coccinellid species or periods of low activity, like estival diapause as it has been noted in other coccinellid species (Katsoyannos, 1984). The variable phenologies of coccinellids probably ensure that aphids will be attacked by these natural enemies throughout the whole season, and therefore may result in an efficient biological control (Holland et al., 2008). The coccinellid assemblage was dominated by one species, $H$. variegata, which alone accounted for $62 \%$ of the total captured individuals. The other species occurred in less than 5.4\% each. In studies parallel to this, where coccinellids were sampled inside the alfalfa fields, 12 out of the 13 species were also found, with $H$. variegata being also the dominant species (57\%), followed by $E$. connexa and $H$. convergens. The only absent species inside the fields were $P$. picta and $H$. axyridis (Grez et al. in prep). This consistency suggests that the assemblages collected in the edges are not merely flying above alfalfa fields but they are also using alfalfa as habitat. The dominance of a few coccinellid species in arable crops is a common phenomenon (Honek and Hodek, 1996). For example, in alfalfa fields in Spain H. variegata, Coccinella septempunctata L. and Scymnus spp. constituted more than $90 \%$ of the coccinellid assemblage (Pons et al., 2005). Furthermore, at our study site, the exotic species accounted for over $75 \%$ of all captures, which suggests that native 
species may be negatively impacted by them as it has been reported from other regions (Obrycki et al., 1998; Turnock et al., 2003; Evans, 200

Finally, coccinellids were similarly collected in both sides of the sticky traps throughout the season (average per trap $\pm 1 \mathrm{SE}, 155.8 \pm 15.3$ and $151.6 \pm 11.6$, in the interior and exterior side of the trap, respectively). It is assumed that the side of the trap facing the crop captures emigrating insects and the side facing the edge vegetation captures immigrating individuals (Duelli et al., 1990). If this assumption is correct, our results suggest that coccinellids are not only moving toward alfalfa fields from adjacent vegetation, but also that alfalfa may act as a reservoir of aphid predators for other arable crops in the vicinity (Pons et al., 2005).

In summary, our results suggest that most species of coccinellids were not affected by crop edges, probably because they are habitat generalists. Nevertheless, tall permanent edges may enhance the arrival of some coccinellid species to alfalfa fields, although the consequences on aphid control remain unclear. Therefore, it would be worthy to acquire additional data on the direct and indirect effects of different field edges on aphid populations in crops, to understand the effectiveness of edges as a conservation biological control approach.

\section{Acknowledgements}

We thank many people who helped us in the field and with the counting of coccinellids in the laboratory: Elizabeth Gazzano, Constanza Rodríguez, Yendery Cerda and the team from the Entomology Lab at P. Universidad Católica de Chile. Thanks also to all the field owners at Pirque for allowing us to access to their alfalfa fields, to Guillermo González for permitting us the use of his coccinellid figures, and to one anonymous referee who significantly help to improve the manuscript. This study was financially supported by FONDECYT 1070412.

\title{
Resumen
}

\begin{abstract}
A. A. Grez, C. Torres, T. Zaviezo, B. Lavandero y M. Ramírez. Migración de coccinélidos a campos de alfalfa que varían en la vegetación adyacente en Chile central. 2010. Cien. Inv. Agr. 37(2): 111-121. Bordes permanentes y permeables favorecerían la llegada de los enemigos naturales a los cultivos. Se evaluó la abundancia y riqueza de especies de coccinélidos migrando a campos de alfalfa adyacentes a Eucalyptus, una mezcla de Falsa acacia, zarzamoras y álamos (F-B-P), viñas, maíz y cultivos anuales bajos. También se estimó la abundancia de áfidos en los campos de alfalfa. Entre septiembre 2007 y mayo 2008, los coccinélidos fueron capturados en tres trampas pegajosas $\left(2,64 \mathrm{~m}^{2}\right)$ ubicadas en el borde de cada alfalfal; la abundancia de áfidos dentro de los alfalfales se estimó en primavera, verano y otoño. Se colectaron 90.396 coccinélidos de 14 especies. Ni la abundancia total ni la riqueza de especies de coccinélidos fueron significativamente afectados por el tipo de vegetación adyacente, pero Adalia deficiens, Psyllobora picta y Cycloneda sanguinea fueron más capturadas en campos de alfalfa adyacentes a Eucalyptus y F-B-P, Olla v-nigrum cerca de cultivos anuales e Hyperaspis sphaeridioides cerca de viñas. La altura y orientación de los bordes explican el $94 \%$ de la varianza de la abundancia de especies. Psyllobora picta fue positivamente influenciada por la altura, O. v-nigrum negativamente e Hyperaspis sphaeridioides negativamente afectada por la exposición norte; ninguna de las especies fue afectada por la permeabilidad del borde. Los áfidos fueron menos abundantes en alfalfales cercanos a F-B-P. En general, la mayoría de las especies de coccinélidos no fueron afectadas por el tipo de borde, pero los bordes altos y permanentes facilitan la llegada de algunas especies de coccinélidos a los campos de alfalfa.
\end{abstract}

Palabras clave: Agroecosistemas, coccinélidos, control biológico de conservación, efectos de borde, enemigos naturales, migración. 


\section{References}

Apablaza, J.U., and T.R. Stevenson. 1995. Fluctuaciones poblacionales de áfidos y de otros artrópodos en el follaje de alfalfa cultivada en la Región Metropolitana. Ciencia e Investigación Agraria 22: $115-121$.

Artigas, J.N. 1994. Entomología Económica: insectos de interés agrícola, forestal, médico y veterinario. Vol. 1. Ediciones Universidad de Concepción. Concepción, Chile. 1126 pp.

Benton, T.G., J.A. Vickery, and J.D. Wilson. 2003. Farmland biodiversity: is habitat heterogeneity the key? Trends in Ecology and Evolution 18: 182-188.

Blackman, R.L., and V.F. Eastop. 2000. Aphids of the world crops: An identification and information guide. John Wiley, New York. 466 pp.

Blackshaw, R.P., and R.S. Vernon. 2006. Spatiotemporal stability of two beetle populations in non-farmed habitats in an agricultural landscape. Journal of Applied Ecology 43: 680-689.

Concepción, E.D., M. Díaz, and R.A. Baquero. 2008. Effects of landscape complexity on the ecological effectiveness of agri-environment schemes. Landscape Ecology 23: 135-148.

CSIRO. 1996. The insects of Australia: a textbook for students and research workers. Melbourne University Press, Carlton, Victoria.1137 pp.

Dixon, A.F.G. 2000. Insect-predator-prey dynamics: ladybird beetles and biological control. Cambridge University Press, Cambridge. 257 pp.

Duelli, P., and M.K. Obrist. 2003. Regional biodiversity in an agricultural landscape: the contribution of semi-natural habitats islands. Basic and Applied Ecology 4: 129-138.

Duelli, P., M. Studer, I. Marchand, and S. Jakob. 1990. Population movement of arthropods between natural and cultivated areas. Biological Conservation 54: 193-207.

Evans, E.W. 2004. Habitat displacement of North American ladybirds by an introduced species. Ecology 85: 637-647.

Gardiner, M.M., D.A. Landis, C. Gratton, C.D. DiFonzo, M. O’Neal, J.M. Chacon, M.T. Wayo, N.P. Schmidt, E.E. Mueller, and G.E. Heimpel. 2009. Landscape diversity enhances biological control of an introduced crop pest in the northcentral USA. Ecological Applications 19: 143154.
González, G. 2006. Los Coccinélidos de Chile. Available online at: http://www.coccinellidae.cl Website accessed: 16 March, 2009.

González, G. 2008. Lista y distribución geográfica de especies de Coccinellidae (Insecta: Coleoptera) presentes en Chile. Boletín del Museo Nacional de Historia Natural (Chile) 57: 77-107.

Grez, A.A., and E. Prado. 2000. Effect of plant patch shape and surrounding vegetation on the dynamics of predatory Coccinellids and their prey, the cabbage aphid Brevicoryne brassicae. Environmental Entomology 29: 1244-1250.

Grez, A.A., T. Zaviezo, S. Díaz, B. Camousseigt, and G. Cortés. 2008. Effects of habitat loss and fragmentation on the abundance and species richness of aphidophagous beetles and aphids in experimental alfalfa landscapes. European Journal of Entomology 105: 411-420.

Griffiths, G.J.K., J.M. Holland, A. Bailey, and M.B. Thomas. 2008. Efficacy and economics of shelter habitats for conservation biological control. Biological Control 45: 200-209.

Holland, J.M., T. Birkett, and S. Southway. 2009. Contrasting the farm-scale spatio-temporal dynamics of boundary and field overwintering predatory beetles in arable crops. Biocontrol 54: 19-33.

Holland, J.M., H. Oaten, S. Southway, and S. Moreby. 2008. The effectiveness of field margin enhancement for cereal aphid control by different natural enemy guilds. Biological Control 47: 71-76.

Holland, J.M., C.F.G. Thomas, T. Birkett, S. Southway, and H. Oaten. 2005. Farm-scale spatiotemporal dynamics of predatory beetles in arable crops. Journal of Applied Ecology 42: 11401152.

Holland, J.M., L. Winder, C. Woolley, C.J. Alexander, and J.N. Perry. 2004. The spatial dynamics of crop and ground active predatory arthropods and their aphid prey in winter wheat. Bulletin of Entomological Research 94: 419-431.

Honek, A., and I. Hodek. 1996. Distribution in habitats. p. 95-141. In: I. Hodek and A. Honek (eds.). Ecology of Coccinellidae. Kluwer Academic Publishers, Massachusetts.

Honek, A., Z. Martinkova, and S. Pekar. 2007. Aggregation characteristics of three species of Coccinellidae (Coleoptera) at hibernation sites. European Journal of Entomology 104: 51-56. 
Hurlbert, S.H. 1984. Pseudoreplication and the design of ecological field experiments. Ecological Monographs 54: 187-211.

Katsoyannos, P. 1984. The establishment of Rhyzobius forestieri (Col.: Coccinellidae) in Greece and its efficiency as an auxiliary control agent against a heavy infestation of Saissetia oleae (Hom.: Coccidae). Entomophaga 29: 387-397.

Landis, D.A., S.D. Wratten, and G.M. Gurr. 2000. Habitat management to conserve natural enemies of arthropod pests in agriculture. Annual Review of Entomology 45: 175-201.

Legendre, P., and L. Legendre. 1998. Numerical Ecology, 2nd English edition. Elsevier, Amsterdam. 853 pp.

Leps, J., and P. Smilauer. 2003. Multivariate analysis of Ecological Data. Cambridge University Press, Cambridge. 269 pp.

Lindborg, R., J. Bengstsson, A. Berg, S.A.O. Cousins, O. Eriksson, T. Gustafsson, K. per Hassund, L. Lenoir, A. Pihlgren, E. Sjödin, and M. Stenseke. 2008. A landscape perspective on conservation of semi-natural grasslands. Agriculture, Ecosystems and Environment 125: 213 222.

Öberg, S., S. Mayr, and J. Dauber. 2008. Landscape effects on recolonisation patterns of spiders in arable fields. Agriculture, Ecosystems and Environment 123: 211-218.

Obrycki, J.J., and T.T. Kring. 1998. Predaceous Coccinellidae in biological control. Annual Review of Entomology 58: 839-845.

Obrycki, J.J., K.L. Giles, and A.M. Ormond. 1998. Interactions between an introduced and indigenous coccinellid species at different prey densities. Oecologia 117: 279-285.

Pollard, K.A., and J.M. Holland 2006. Arthropods within the woody element of hedgerows and their distribution pattern. Agricultural and Forest Entomology 8: 203-211.

Pons, X., E. Núñez, B. Lumbierres, and R. Albajes. 2005. Epigeal aphidophagous predators and the role of alfalfa as a reservoir of aphid predators for arable crops. European Journal of Entomology 102: 519-525.

Rojas, S. 2005. Control Biológico de Plagas en Chile. Historia y Avances. Instituto de Investigaciones Agropecuarias. Santiago, Chile. 123 pp.

Sokal, R.R., and F.J. Rohlf. 1995. Biometry: the principles and practice of statistics in biological research. Freeman, New York, New York. 887 pp.

StatSoft. 2001. Statistica: Data analysis software system. StatSoft, Tulsa.

Sutherland, J.P., M.S. Sullivan, and G.M. Poppy. 2001. Distribution and abundance of aphidophagous hoverfies (Diptera: Syrphidae) in wildflower patches and field margin habitats. Agricultural and Forest Entomology 3: 57-64.

ter Braak, C., and P. Smilauer. 1998. Canoco reference manual and user's guide to Canoco for Windows: software for canonical community ordination (version 4). Microcomputer Power, Ithaca, New York.

ter Braak, C.J.F., and P. Smilauer. 2002. CANOCO Reference Manual and CanoDraw for Windows User's Guide: Software for Canonical Community Ordination (version 4.5). Microcomputer Power, Ithaca New York.

Tscharntke, T., R. Bommarco, Y. Clough, T.O. Crist, D. Kleijn, T.A. Rand, J.M. Tylianakis, S. van Nouhuys, and S. Vidal. 2007 Conservation biological control and enemy diversity on a landscape scale. Biological Control 43: 294-309.

Turnock, W.J., I.L. Wise, and F.O. Matheson. 2003. Abundance of some native coccinellines (Coleoptera: Coccinellidae) before and after the appearance of Coccinella septempunctata. Canadian Entomologist 135: 391-404.

Zaviezo, T., A.A. Grez, and D. Donoso. 2004. Dinámica temporal de coleópteros asociados a alfalfa. Ciencia e Investigación Agraria 31: 29-38.

Zaviezo, T., A.A. Grez, C.F. Estades, and A. Pérez. 2006. Effects of habitat loss, habitat fragmentation and isolation on the density, species richness and distribution of ladybeetles in manipulated alfalfa landscapes. Ecological Entomology 31: 646-656. 
